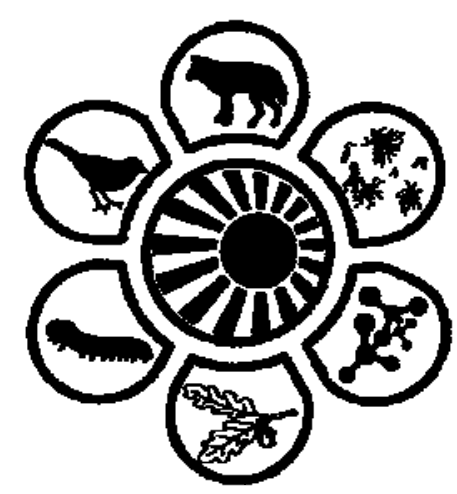

Вісник Дніпропетровського університету. Біологія, екологія.

Vìsnik Dnìpropetrovs'kogo unìversitetu. Serîa Bìologîâ, ekologiâ

Visnyk of Dnipropetrovsk University. Biology, ecology.

Vìsn. Dnìpropetr. Unìv. Ser. Bìol. Ekol. 2016. 24(2), 473-483.

doi: $10.15421 / 011664$

ISSN 2310-0842 print

ISSN 2312-301X online

www.ecology.dp.ua

UDC 574.21+574.476

\title{
Functional and spatial structure of the urbotechnozem mesopedobiont community
}

\author{
O.N. Kunah \\ Oles Honchar Dnipropetrovsk National University, \\ Dnipropetrovsk, Ukraine
}

The results of studying the spatial structure of soil mesofauna of an urbanotechnozem by OMI- and RLQ-analysis are presented. The research was conducted on 5 June 2012 in the Botanic Garden of Oles Gonchar University (previously - territory of the Park Y. Gagarin, Dnipropetrovsk). The studied plot is situated on the slope of the Krasnopostachekaya balka $\left(48^{\circ} 25^{\prime} 57.43^{\prime \prime} \mathrm{N}, 35^{\circ} 2^{\prime} 16.52^{\prime \prime} \mathrm{E}\right)$. The plot consists of 15 transects directed in a perpendicular manner in relation to the talweg. Each transect is made of seven sample points. The distance between points is $2 \mathrm{~m}$. The coordinates of the lower left point were taken as $(0 ; 0)$. The plot consisted of artificial grassland with a single tree. The vegetation was composed of grassland and steppe, of a mega-mesotrophic, xeromesophilic character. At each point the mesopedobionts were studied (data presented as L-table); temperature, electrical conductivity and soil penetration resistance, and grass height were measured (data presented as R-table). The soil-zoological test area was $25 \times 25 \mathrm{~cm}$. The mesopedobiont community was represented by 28 species and with total abundance $70.1 \mathrm{ind} . \mathrm{m}^{2}$. The following groups were dominant in the ecological structure of the soil animal community; saprohages, pratants, mesotrophocoenomorphs and the endogeic group. The measured edaphic characteristics were shown to play an important role in structurization of the ecological niche of the mesopedobiont community. The usage of morphological or physiological features of animals for the assessment of degree of specific distinctions is applicable for homogeneous taxonomic or ecological groups possessing comparable characteristics which also can be interpreted ecologically. The soil mesofauna is characterized by high taxonomic and ecological diversity of forms, which are difficult to compare by morphological or physiological criteria. The ecological value of characteristics in different groups will be not identical, and the basis for their comparison will be inadequate. Therefore we apply to the description of ecological features an ecomorphic analysis of the soil animals. The organization of communities of soil animals may be considered at the levels of investigated point,biogeocenosis, landscape and regional level. On the basis of landscape-ecological distribution of species in ecological space, their distribution in ecological groups - ecomorphs is established. The regular ratio of an ecomorph in these functional groups will be reflection of their organizational structure and ecological diversity. The obtained data testifies to the justice of this assumption. It is important to note the fact that the functional groups allocated in ecological space by means of the RLQ-analysis show regular patterns of spatial variability. Local functional groups are characterized by ecological characteristics in which any ecomorph may contain species occupying different hierarchical positions. Ascertaining the spatial heterogeneity of the animal community and determinancy of properties of an ecological niche by soil factors is an important result. However, for understanding of the nature of heterogeneity of the spatial variant of ecomorphs the analysis with RLQ-analysis application has been processed. Within a comparatively uniform field the spatial differentiation of the animal community in functional groups has been found. The reality of their existence was not only verified statistically, but also supplemented by a substantial interpretation of the ecomorphic markers of the interrelations between the groups and indicators of the ecological properties of the soil they inhabit. The variation of environmental properties within microsites leads to rearrangement of the ecological frame of the soil animal community. Heterogeneity of a soil body and vegetation mosaic form patterns of the spatial organisation of the soil animal community.

Keywords: mesopedobionts; ecological niche; spatial ecology; ecomorphs

Днепропетровский национальный университет имени Олеся Гончара, пр. Гагарина, 72, Днепропетровск, 49010, Украина Oles Honchar Dnipropetrovsk National University, Gagarin Ave., 72, Dnipropetrovsk, 49010, Ukraine Tel.: +38-067-993-55-13. E-mail: olga-kunakh@rambler.ru 


\title{
Функциональная и пространственная структура сообщества мезопедобионтов урботехнозема
}

\author{
О.Н. Кунах
}

\author{
Днепропетровский национальньій университет имени Олеся Гончара, Днепропетровск, Украина
}

\begin{abstract}
Приведены результаты изучения пространственного варьирования экоморфической структуры почвенной мезофауны технозема методами OMI- и RLQ-анализа. Биогеоценотическая обстановка в месте расположения экспериментального полигона имеет лугово-степной мегамезотрофный ксеромезофильный облик. Данные для исследования собраны с помощью ручной разборки почвенных образцов площадью $0,25 \times 0,25$ м по регулярной сетке $(7 \times 15$ образцов) с расстоянием между точками отбора 2 м (результаты представлены как L-таблица), проведено измерение температуры, электропроводности и твердости почвы, мощности подстилки и высоты травостоя (R-таблица). Почвенная мезофауна экспериментального участка представлена 28 видами с общей плотностью 70,1 экз./м². В экологической структуре животного населения почвы преобладают пратанты, мезотрофоценоморфы, эндогейные беспозвоночные, сапрофаги. Такие эдафические характеристики как твердость почвы, электропроводность, мощность подстилки, а также высота травостоя играют важную роль в структурировании экологической ниши сообщества мезопедобионтов. Первые две оси ОМІ-анализа описывают 71,5\% инерции, что вполне достаточно для того, чтобы описание дифференциации экологических ниш мезофауны на изучаемом полигоне проводилось в пространстве первых двух осей. Для среднего значения маргинальности сообщества $(\mathrm{OMI}=3,32)$ уровень значимости составляет $\mathrm{P}=0,001$, что свидетельствует о важной роли выбранных переменных среды для структурирования сообщества почвенной мезофауны. B результате RLQ-анализа и последующей кластерной процедуры выявлены четыре ключевые функциональные группы мезопедобионтов и найдена роль эдафических факторов в их пространственном варьировании. Каждая из функциональных групп интерпретирована в терминах экоморфического подхода.
\end{abstract}

Ключевые слова: почвенная мезофауна; экологическая ниша; пространственная экология; экоморфы

\section{Introduction}

Evaluation of the properties of habitats is essential for forecasting the impact of disturbances on communities of living organisms and to identify the properties of the environment that are important for the protection of biodiversity and maintenance of ecosystem functions (Brind'Amour et al., 2011; Brygadyrenko, 2015). Differences in species composition and community variability in response to environmental conditions are a key obstacle to the development of habitat models that could be applied to different types in various ecosystems (Olden and Jackson, 2002; Faly and Brygadyrenko, 2014). Functional classification of animals into groups whose species are characterized by common ecological features provides an alternative to the individual model-type of environment and can bypass these obstacles (McGill et al., 2006; Brind'Amour et al., 2011). Groups of species that share common environmental properties form the operational units that respond to environmental factors and are more predictable than individual species, greatly increasing the predictive ability of the model habitats compared to models created for high levels of taxonomic resolution, such as the species level (Austen et al., 1994). Combination of species according to their ecological features is also a method for identifying functional groups of species in order to assess key ecosystem functions, this being the most important step for clarifying functional diversity within and between ecosystems (Brind'Amour et al., 2005; Mouillot et al., 2006). The hypothesis of habitat filtering suggests that species with similar ecological requirements form a functional group which occupies similar habitats (Tonn et al., 1990; Zobel, 1997; Brygadyrenko and Komarov, 2008). Combining species on grounds such as morphology, or behavior, is one way to simplify the study of a variety in species communities (Angermeier and Winston, 1998).

The relationship between the species characteristics and properties of the environment are usually evaluated indirectly using the following two-step analysis. First, the abundance of species associated with the environmental conditions and the types of reaction to the changing environment, then the properties relating to biological or physiological characteristics of the species (Thuiller et al., 2004; Santoul et al., 2005; Brind'Amour et al., 2011). RQL analysis allows us to correlate ecological characteristics of species to environmental conditions (Doledec et al. 1996). This article examines the joint structure as presented in three data tables: the R-table (containing environmental variables), the Q-table (containing species characteristics) and the L-table (species abundance) (Doledec et al., 1996; Dray et al., 2002). The L-table performs a connection function between the tables $\mathrm{R}$ and $\mathrm{Q}$, and measures the intensity of the connection between them. Before the actual analysis, three separate analyses were conducted. Correspondence analysis is applied on the L-tables and gives the optimal correlation structure between the study sites and the species scores. Ordination of tables $\mathrm{R}$ and $\mathrm{Q}$ is performed by principal component analysis. Thus, RQL performs co-inertia analysis on the cross-matrix of R, Q, and L. This analysis maximizes the covariance between the studied site's scores constrained by environmental variables of table $\mathrm{R}$ and the species scores constrained by the traits of table Q (Minden et al., 2012). The result could be obtained by a combination of the best coordination in their environmental characteristics, the ordination of species by their attributes (traits), and the simultaneous ordination of species and sites (Thuiller et al., 2006). The RQL-analysis combines the three separate ordination solutions to maximize the covariance between the traits of species and environmental data via the use of coinertia analysis (Bernhardt-Romermann et al., 2008). Next, a hierarchical cluster analysis of the balance of species in two axes is made by RQL. The Ward method enables us to extract the functional groups (Minden et al., 2012). The optimal number of groups can be determined using Calinski criteria (Calinski and Harabasz, 1974). The clusters show the distribution of functional groups in the traits-environment space (Minden et al., 2012).

The soil animal community is a reliable indicator of the direction of biogeocenotic processes (Gilyarov, 1965). This is true for artificial soil-like structures - technozems. Disadvantages of design of this technozem may be accurately di- 
agnosed by the specifics of the spatial organization of the mesopedobiont community (Andrusevych et al., 2014). RLQ-analysis allows us to evaluate the relationship between the three most important characteristics of the soil ecosystem: edaphic factors, species diversity and ecomorphic structure (Kunah et al., 2013). The ecomorphs reflect the adaptation of animals to different aspects of the biogeocenotic environment (Zhukov, 2009). In a particular community the observed variability of the ecomorphs' conjunctions makes it possible to give a multidimensional characterization of its ecomorphic organization.

Physical soil characteristics describe environmental conditions in the soil (Karpachevsky, 2010). Technozems are an artificial soil-like structure characterized by a high variability of properties (Shemavnev et al., 2005; Zadorozhna et al., 2012; Zhukov and Zadorozhna, 2013, Demidov et al., 2013). To characterize the spatial heterogeneity of soil as a habitat for soil animals we selected indicators that meet two requirements (Kunah et al., 2013, 2014; Zhukov et al., 2014). First of all, it is the environmental relevance that means performance, which is capable of informative display of features of the soil as a habitat for plants and soil animals. One further criterion is important to describe the spatial variability of the environmental properties of the indicator, the measurement process should be relatively easy to conduct, i.e. within a short time a significant amount of data may be collected (Kunakh et al., 2013). Such indicators as soil mechanical impedance, electrical conductivity and temperature of the soil can be quite quickly measured with modern tools which generate a large amount of data, and estimates of the nonuniformity of soil clearly correlate with the properties of the soil inhabited by the animal population. This approach has been shown to be effective in the study of forest biogeocenosis soil mesofauna (Kunah and Baldin, 2011), forest urbanozem (Kunah et al., 2013; Pakhomov et al., 2013), the spatial distribution of mole rats' mounds (Zhukov et al., 2013), the role of pedoturbation activity of mole rats in the structuring of the spatial organization of the herpetobiont spiders community (Zhukov et al., 2011).

Analysis of species' ecological niche marginality showed that a visually homogeneous and relatively small plot of land is a diverse habitat for soil animals. It was found that the design features of a tehnozem, which manifest themselves through the variability of the soil's mechanical impedance in horizontal and vertical directions lead to a significant differentiation of the soil animal population of this area. The variability of the soil's mechanical impedance also impacts on the water regime of the soil, which affects the vegetation area and is quantitatively reflected in terms of electrical conductivity and temperature of the soil, as well as the height of the grass (Pakhomov et al., 2013).

The aim of the investigation is to study the spatial organization of the ecomorphic aspect of the mesopedobiont community of a model polygon within an urban area under intensive recreational load (Botanical Garden of Oles Honchar Dnipropetrovsk National University, Dnipropetrovsk).

\section{Material and methods}

The study was performed on 13 June 2012 in the Botanical Garden of DNU named after Oles Gonchar (previously - the territory of the park was named after Yuri Gagarin, Dnipropetrovsk). The test polygon N 12 is located in the talweg of a branch of the Krasnopovstancheskaya balka $\left(48^{\circ} 25^{\prime} 55.24^{\prime \prime} \mathrm{N}, 35^{\circ} 02 ' 20.27^{\prime \prime} \mathrm{E}\right)$. Spatial placement of the polygon is presented in the article by Baluk et al. (2014). The natural talweg and part of the slope is covered with a mixture of technical construction waste, on which artificial soil formed. The soil at the study site is urbotechnozem (sod urbopedozem on technical construction waste mixture, since the establishment of the soil structure of the upper layer a chernozem-like mass was formed) (Mirzak, 2001). The soil of the investigated polygon was referred by Kabar (2003) to an order of anthropogenic soil, type - technozem, subtype black soil technozem, the genus - humous, lithographic series - heterogeneous, species - with low humus content, with middle depth of soil layer, variety - median-loamy.

The investigated polygon represents a regular grid with $7 \times$ 15 sample points. The distance between sampling points was $2 \mathrm{~m}$. The size of the plot was $18 \times 42 \mathrm{~m}$.

The site is an artificial lawn with isolated planted trees. Forest plants are represented by Norway maple (Acer platanoides L.) and box elder (A. negundo L.). In the sward the following plants are abundant; orchard grass (Dactylis glomerata L.), Volga fescue (Festuca valesiaca Goud. Sl), large salsify (Tragopogon major Jacq.) and field sow thistle (Sonchus arvensis L.). The vegetation is meadow-steppe in appearance $(44.4 \%$ of the projective cover is represented by the meadow coenomorph, and $37.0 \%$ by the steppe coenomorph). Phytoindication assessment allows trophotopes of the studied polygon to be assessed as a megamesotrophic (mesotroph projective cover is $59.3 \%$, the other is megatroph). The hygrotop generally has a xeromesophilous character (xeromesophiles' projective cover is $33.3 \%$ ).

At each point soil-zoological samples were taken to collect mesopedobionts (the size category of the soil animals was equivalent to macrofauna). The soil zoological samples measured $25 \times 25 \mathrm{~cm}$. Results are shown in the L-table. Soil temperature (layer $0-5 \mathrm{~cm}$ ), soil electrical conductivity, soil mechanical impedance, depth of litter layer and height of grass were measured (presented in the R-table).

Measurements of mechanical impedance of the soil were carried out in field conditions to a depth of $100 \mathrm{~cm}$ at intervals of $5 \mathrm{~cm}$. Mechanical impedance of the soil was recorded using a cone-penetrometer (Eijkelkamp Agrisearch Equipment, the Netherlands) (Zhukov and Zadorozhnaya, 2016). The average error of device measurement results is $8 \%$. Measurements of mechanical impedance of the soil were made by a cone of cross-section $2 \mathrm{~cm}^{2}$ in each cell of range.

Soil electrical conductivity was measured in situ by HI 76305 (Hanna Instruments, Woonsocket, R.I.). The HI 76305 is an amperometric steel probe that can be inserted directly into the soil or substrate and is connected to a HI 993310 portable water conductivity and soil salinity meter. The probe measures the total conductivity of the soil, i.e. the combined conductivity of air, water, and soil particles or substrate components (Scoggins and van Iersel, 2006).

Soil temperature was measured over 13 to 14 hours with a digital thermometer WT-1 (PJSC "Steklopribor", $\mathrm{http} / / /$ bit.steklopribor.com, accuracy is $0.1^{\circ} \mathrm{C}$ ) at a depth of 5-7 cm. Depth of the litter layer and grass height were measured by ruler. Measurements of electrical conductivity, tem- 
perature, litter layer depth and grass height were made in triplicate at each test point.

The characteristics of plant ecomorphs are presented according Belgard (1950) and Tarasov (2005, 2012), the Q-table is represented by soil animals ecomorphs (Zhukov, 2006, 2007, 2009; Zhukov et al., 2007). Statistical procedure RLQ and OMI-analyses were performed using the ade4 package for R (The R Foundation, 2010). The significance of RLQ was evaluated using the procedure randtest.rlq. The essence and characteristics of OMI-analysis is discussed in the work of Pakhomov et al. (2013).

\section{Results and discussion}

The characteristic of the taxonomic and ecological diversity of the mesopedobiont community within the studied polygon is presented in Table 1 .
At the study site 28 species of soil animals were found. The abundance of the mesopedobiont community of the studied polygon was $70.06 \pm 15.67 \mathrm{ind} . / \mathrm{m}^{2}$. Earthworms were a numerous and diverse group of saprophagous species within the site and were represented by 4 species. Earthworms made up $61.6 \%$ of the total mesopedobiont community density. The dominant species was the endogeic Aporrectodea $c$. trapezoides. Its abundance was 31.70 ind. $/ \mathrm{m}^{2}$. Endogeic earthworms were also represented by Octolasion lacteum and Aporrectodea r. rosea, and epigeic species were represented by Lumbricus rubellus. Earthworm hygromorphs were represented by hygrophylous and mesophylous species. The range of the cenomorphs was also very wide. Among earthworms, stepants, pratants and silvants were represented. Thus, the earthworm complex of the studied polygon was abundant and diverse in taxonomic and ecological aspects.

Composition and abundance of species composing the mesopedobiont community

Table 1

\begin{tabular}{|c|c|c|c|c|c|c|c|c|}
\hline Family & Species & $\begin{array}{l}\text { Coeno- } \\
\text { morph }\end{array}$ & $\begin{array}{l}\text { Hygro- } \\
\text { morph }\end{array}$ & $\begin{array}{l}\text { Coeno- } \\
\text { tropho- } \\
\text { moph }\end{array}$ & $\begin{array}{l}\text { Topo- } \\
\text { morph }\end{array}$ & $\begin{array}{l}\text { Tropho- } \\
\text { morph }\end{array}$ & $\begin{array}{l}\text { Phoro- } \\
\text { morph }\end{array}$ & $\begin{array}{c}\text { Abundance, } \\
\mathrm{x} \pm \mathrm{SE} \\
\text { ind. } / \mathrm{m}^{2}\end{array}$ \\
\hline \multirow{4}{*}{ Lumbricidae } & Aporrectodea caliginosa trapezoides (Duges, 1828) & $\operatorname{Pr}$ & Ms & MsTr & End & SF & B4 & $31.70 \pm 3.88$ \\
\hline & A. rosea rosea (Savigny, 1826$)$ & St & Ms & $\mathrm{MgTr}$ & End & SF & B4 & $1.68 \pm 0.62$ \\
\hline & Lumbricus rubellus Hoffmeister, 1843 & Sil & $\mathrm{Hg}$ & MsTr & Ep & $\mathrm{SF}$ & B4 & $7.92 \pm 1.36$ \\
\hline & Octolasion lacteum (Oerley, 1885) & Sil & Ms & $\operatorname{MsTr}$ & End & SF & B4 & $1.83 \pm 0.70$ \\
\hline Aranei & Aranea spp. & St & Ms & MsTr & Ep & $\mathrm{ZF}$ & A3 & $1.22 \pm 0.41$ \\
\hline Phalangiidae & Zacheus lupatus (Eichwald, 1830) & St & $\mathrm{Ks}$ & MsTr & Ep & $\mathrm{ZF}$ & A3 & $0.30 \pm 0.21$ \\
\hline Geophilidae & Geophilus proximus C.L.Koch, 1847 & $\operatorname{Pr}$ & $\mathrm{Hg}$ & $\mathrm{MsTr}$ & Anec & $\mathrm{ZF}$ & $\mathrm{A} 2$ & $8.38 \pm 1.44$ \\
\hline Julidae & Megaphyllum rossicum (Timotheew, 1897) & $\operatorname{Pr}$ & Ms & $\operatorname{MgTr}$ & Ep & SF & A3 & $0.91 \pm 0.36$ \\
\hline Polydesmidae & Schizothuranius dmitriewi (Timotheew, 1897) & $\operatorname{Pr}$ & $\mathrm{UHg}$ & $\mathrm{MsTr}$ & Ep & SF & A3 & $1.83 \pm 0.73$ \\
\hline Cantharididae & Cantharis rustica Fallen, 1807 & St & Ks & MsTr & Ep & $\mathrm{ZF}$ & A3 & $0.15 \pm 0.15$ \\
\hline \multirow{3}{*}{ Carabidae } & Bembidion sp. & Sil & $\mathrm{Hg}$ & $\mathrm{O} \lg \operatorname{Tr}$ & Ep & $\mathrm{ZF}$ & $\mathrm{A} 1$ & $0.76 \pm 0.32$ \\
\hline & Carabidae sp. (larv.) & St & Ms & $\mathrm{O} \lg \operatorname{Tr}$ & Ep & $\mathrm{ZF}$ & $\mathrm{A} 3$ & $1.07 \pm 0.49$ \\
\hline & Harpalus sp. & St & Ms & MsTr & Ep & $\mathrm{FF}$ & A1 & $0.30 \pm 0.22$ \\
\hline Cerambicidae & Dorcadion fulvum (Scopoli, 1763) & St & Ks & $\mathrm{UMgTr}$ & End & FF & B4 & $0.15 \pm 0.15$ \\
\hline Coccinellidae & Coccinella septempunctata Linnaeus, 1758 & $\operatorname{Pr}$ & Ks & MsTr & Ep & $\mathrm{ZF}$ & B7 & $0.15 \pm 0.15$ \\
\hline Dermestidae & Dermestes laniarius Illiger, 1801 & St & Ks & UMgTr & Ep & $\mathrm{ZF}$ & $\mathrm{A} 1$ & $0.15 \pm 0.15$ \\
\hline Elateridae & Elateridae spp. & Pal & Ms & MsTr & End & $\mathrm{FF}$ & B5 & $0.15 \pm 0.15$ \\
\hline \multirow{2}{*}{ Scarabaeidae } & Melolontha melolontha (Linnaeus, 1758) & St & $\mathrm{Ks}$ & $\mathrm{MsTr}$ & End & $\mathrm{FF}$ & B7 & $1.37 \pm 0.45$ \\
\hline & \begin{tabular}{|l|} 
Rhizotrogus aestivus (Olivier, 1789) \\
\end{tabular} & St & Ms & UMgTr & End & FF & $\mathrm{B} 7$ & $0.15 \pm 0.15$ \\
\hline Staphilinidae & Staphylinus caesareus Cederhjelm, 1798 & Sil & Ms & MsTr & Ep & $\mathrm{ZF}$ & A1 & $0.15 \pm 0.15$ \\
\hline Noctuidae & Lepidoptera spp. & Sil & Ks & MsTr & End & $\mathrm{FF}$ & B4 & $1.22 \pm 0.42$ \\
\hline Trachelipodidae & Trachelipus rathkii (Brandt, 1833) & $\operatorname{Pr}$ & $\mathrm{UHg}$ & MsTr & Ep & SF & $\mathrm{A} 3$ & $1.83 \pm 0.65$ \\
\hline Enidae & Brephulopsis cylindrica (Menke, 1828) & St & Ks & $\mathrm{MgTr}$ & Ep & $\mathrm{FF}$ & A3 & $0.15 \pm 0.15$ \\
\hline Cochlicopidae & Cochlicopa lubrica (Müller, 1774) & Sil & $\mathrm{Hg}$ & MsTr & Ep & FF & A1 & $0.30 \pm 0.22$ \\
\hline Enidae & Chondrula tridens (O.F. Muller, 1774) & St & Ks & $\mathrm{UMgTr}$ & Ep & FF & $\mathrm{A} 3$ & $3.20 \pm 0.79$ \\
\hline Gastrodontidae & Zonitoides nitidus (O.F. Muller, 1774) & Pal & $\mathrm{UHg}$ & $\mathrm{UMg} \operatorname{Tr}$ & Ep & $\mathrm{FF}$ & $\mathrm{A} 3$ & $1.52 \pm 0.52$ \\
\hline Limacidae & Limax $s p$ & Sil & $\mathrm{Hg}$ & $\mathrm{Olg} \operatorname{Tr}$ & Ep & FF & B4 & $1.52 \pm 0.68$ \\
\hline
\end{tabular}

Notes: coenomorphs: $\mathrm{St}$ - stepants, Pr - pratants, Pal - pallyudants, Sil - silvants; hygromorphs: Ks - xerophyllous, Ms - mesophyllous, Hg - hygrophyllous, UHg - ultrahygrophyllous; coenotrophomophs: MsTr - mesotrophocoenomorphs; MgTr megatrophocoenomorphs; UMgTr - ultramegatrophocoenomorphs; topomorphs: End - endogeic, Ep - epigeic, Anec - anecic; phoromorphs: A - move using the soil porosity; B - active burrowing; 1 - minimal size of animal body is less than soil pore size; 2 animal body size commensurate with the soil pore size; 3 - animal body size larger than cavities in the litter or commensurate with the large gaps or cracks in the soil; 4 - moving with a change in body thickness; 5 - moving without changes of body thickness; 6 digging holes with limbs; 7 - C-shaped body shape; trophomorphs: SF - saprophagous; FF - phytophagous; ZF - zoophagous.

In addition to the earthworms, the group of soil saprophages included the millipede Megaphyllum rossicum $(0.91 \pm$ 0.36 ind.$\left./ \mathrm{m}^{2}\right)$, the millipede of the family Polydesmidae Schizothuranius dmitriewi $\left(1.83 \pm 0.30 \mathrm{ind} . / \mathrm{m}^{2}\right)$ and the woodlouse Trachelipus rathkii $\left(1.83 \pm 0.65\right.$ ind. $\left./ \mathrm{m}^{2}\right)$.
Predatory centipedes were represented by Geophilus proximus $\left(8.38 \pm 1.44 \mathrm{ind} . / \mathrm{m}^{2}\right)$, which moves within the system of soil holes and cracks. Predators are also represented by larvae of ground beetles, adult rove beetles Staphylinus caesareus, spiders and harvestmen. 
The group of phytophages was diverse and represented by larvae of noctuid scoop (Noctuidae), beetles (Melolontha melolontha and Rhizotrogus aestivus), ground beetles, the longhorn beetle (Dorcadion fulvum) and molluscs (5 species).

The coenomorphic structure of the mesopedobiont community was constructed on the basis of pratants $(68.6 \%$ in abundance). The proportions of stepants and silvants was almost equal (15.9\% and 14.3\%, respectively) (Fig. 1). Thus, the coenomorphic structure of the mesopedobiont community of the studied polygon can be described as meadow type with steppe and forest elements.

Among hygromorphs, mesophilous species dominated $(60.0 \%)$, with slightly fewer hygrophyllous invertebrates (20.5\%). Both xerophyllous and ultrhygrophyllous species were uncommon $(9.5 \%$ and $10.0 \%$ respectively). The hygromorphic structure of the community may be assessed as mesophyllous. The community was dominated by mesotrophocoenomorphs $(86.5 \%)$. In the topomorph structure endogeic and epigeic forms dominate $(59.5 \%$ and $33.0 \%$ respectively). Anecic invertebrates were significantly less abundant $(7.6 \%)$. Saprophagous invertebrates were the clear dominant in the trophic structure $(76.5 \%)$. The proportion of zoophages was $11.9 \%$, and that of herbivores was $11.6 \%$.

Phoromorphs were dominated by animals which actively burrow, moving by changing their body thickness (phoromorph B4 $-70.0 \%$ ) and those which use the existing system of cavities and whose body size is larger than litter cavities or commensurate with large gaps or cracks in the soil (phoromorph $\mathrm{A} 3-18.6 \%$ ).

Edaphic characteristics can be considered as determinants of the ecological space of the mesopedobiont community (Table 2).

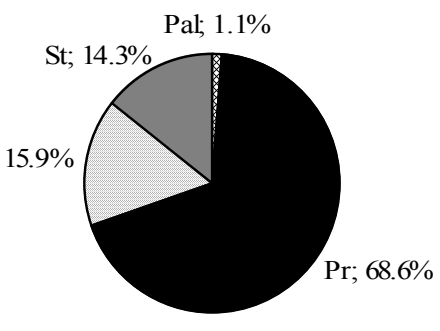

Coenomorphs

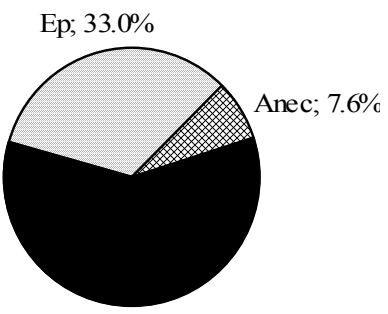

End; $59.5 \%$

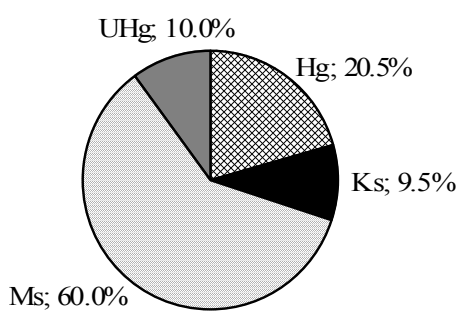

Hygromorphs

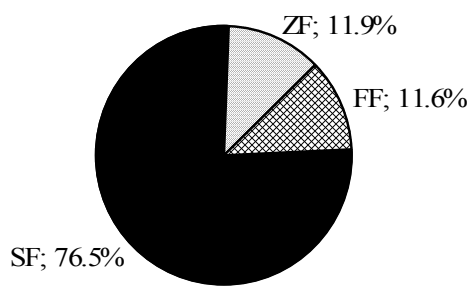

Trophomorphs

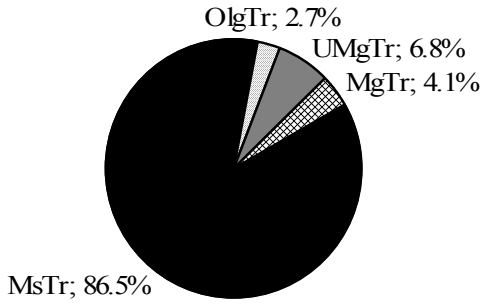

Coenotrophomorphs

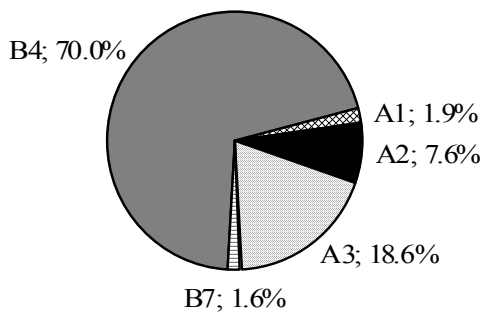

Phoromorphs

Topomorphs

Fig. 1. Ecological structure of the mesopedobiont community: legend see Table 1

Table 2

Determinants of mesopedobiont community in ecological space

\begin{tabular}{|c|c|c|c|c|c|c|}
\hline \multirow{2}{*}{ Environment parameters } & \multirow{2}{*}{ Average } & \multicolumn{2}{|c|}{ Confidence interval } & \multirow{2}{*}{$\mathrm{CV}, \%$} & \multirow{2}{*}{ RLQ axes 1} & \multirow{2}{*}{ RLQ axes 2} \\
\hline & & $-95 \%$ & $+95 \%$ & & & \\
\hline \multicolumn{7}{|c|}{ Soil mechanical impedance on the depth, $\mathrm{MPa}$} \\
\hline $0-5 \mathrm{~cm}$ & 1.78 & 1.69 & 1.87 & 25.06 & -0.53 & 0.10 \\
\hline $5-10 \mathrm{~cm}$ & 2.38 & 2.25 & 2.51 & 27.82 & -0.80 & -0.30 \\
\hline $10-15 \mathrm{~cm}$ & 3.05 & 2.88 & 3.21 & 27.66 & -0.90 & -0.46 \\
\hline $15-20 \mathrm{~cm}$ & 3.81 & 3.62 & 4.00 & 26.26 & -0.86 & -0.64 \\
\hline $20-25 \mathrm{~cm}$ & 4.24 & 4.04 & 4.45 & 25.42 & -0.87 & -0.69 \\
\hline $25-30 \mathrm{~cm}$ & 4.61 & 4.39 & 4.84 & 24.91 & -0.86 & -0.74 \\
\hline $30-35 \mathrm{~cm}$ & 4.75 & 4.50 & 4.99 & 26.54 & -0.86 & -0.75 \\
\hline $35-40 \mathrm{~cm}$ & 4.83 & 4.55 & 5.10 & 29.54 & -0.84 & -0.73 \\
\hline $40-45 \mathrm{~cm}$ & 4.92 & 4.62 & 5.22 & 31.47 & -0.83 & -0.73 \\
\hline $45-50 \mathrm{~cm}$ & 5.00 & 4.68 & 5.32 & 33.04 & -0.82 & -0.74 \\
\hline \multicolumn{7}{|c|}{ Physical properties, litter depth and grass height } \\
\hline Electrical conductivity, $\mathrm{dSm} / \mathrm{cm}$ & 0.48 & 0.45 & 0.51 & 30.39 & 0.23 & -0.15 \\
\hline $\begin{array}{l}\text { Temperature of the soil layer } 5-7 \mathrm{~cm},{ }^{\circ} \mathrm{C} \text {, } \\
10.06 .2012\end{array}$ & 24.71 & 24.12 & 25.29 & 12.22 & 0.38 & -0.36 \\
\hline Litter depth, cm & 1.81 & 1.07 & 2.54 & 210.06 & 0.18 & 0.25 \\
\hline Grass height, $\mathrm{cm}$ & 43.41 & 40.17 & 46.65 & 38.56 & 0.09 & 0.54 \\
\hline
\end{tabular}


In the study polygon, the mechanical impedance of the soil was characterized by a monotonic increase with increasing depth. The upper soil layer's mechanical impedance was on average $1.78 \mathrm{MPa}$, and the bottom $-5.00 \mathrm{MPa}$. The average values of the soil mechanical impedance in the range of the studied polygon exceeded those critical for the growth of plant roots $(3.0-3.5 \mathrm{MPa})$ starting from soil layers of 15$20 \mathrm{~cm}$ (Medvedev, 2009). This suggests a high structuring effect of spatial variability of mechanical impedance of the soil on the organization of the animal community. The coefficient of variation of soil mechanical impedance was characterized by the presence of two local maxima (at a depth of 10-20 and $45-50 \mathrm{~cm})$ and local minima $(0-5$ and $30-35 \mathrm{~cm})$.

The electrical conductivity of the soil was on average $0.48 \mathrm{dS} / \mathrm{cm}$ and characterized by a coefficient of variation of $30.4 \%$. High concentrations of electrolytes begin to exert a negative impact on the vegetation with conductivity values of 1.5-2.0 dS/cm (Smagin et al., 2006). The observed values of the electrical conductivity were significantly lower than these values, indicating a lack of inhibitory effect of vegetation on soil solution, and probably on the animals.

The temperature of the soil layer of 5-7 cm during the study period was $24.7^{\circ} \mathrm{C}$ with the coefficient of variation was $12.2 \%$. The depth of plant litter within the area was $1.81 \mathrm{~cm}$ with a coefficient of variation of $210.1 \%$. The high value of the coefficient of variation is due to the fact that in the 13 sample points there was no litter, and the maximum depth of the litter reached $20-22 \mathrm{~cm}$.

The coefficient of variation for grass height was $38.6 \%$ with an average level of this indicator $43.4 \mathrm{~cm}$.

Joint measurement of edaphic characteristics and features of the animal community structure allowed us to evaluate the properties of the ecological niches of the soil macrofauna (Table 3). The total inertia which can be calculated as a result of OMI-analysis is proportional to the average marginality of species and is a quantitative assessment of the impact of environmental factors on the separation of the species. The analysis found that the total inertia is 1.67 . The first axis, resulting from OMI-analysis describes $52.5 \%$, and the second $-19.0 \%$ inertia. The two first axes of the OMI analysis accounted for $71.5 \%$ of the marginality. As a sequence, the subsequent graph uses only these two axes. For average value of community marginality $(\mathrm{OMI}=3.32)$ the significance level is $P=0.01$, which indicates the importance of the selected environment variables for the structuring of the soil macrofauna community.

Table 3

OMI-analysis of the mesopedobiont community

\begin{tabular}{|l|l|r|r|r|c|c|}
\hline \multicolumn{1}{|c|}{ Species } & \multicolumn{1}{c|}{ Acronym } & Inertia & OMI & Tol & Rtol & $p$-level \\
\hline Aporrectodea trapezoides & A_trapezoides & 12.94 & 8.70 & 24.20 & 67.10 & 0,02 \\
\hline Aporrectodea rosea & A_rosea & 14.64 & 31.70 & 28.70 & 39.50 & 0,05 \\
\hline Aranea sp. & Aranea & 24.73 & 11.60 & 13.10 & 75.30 & 0,13 \\
\hline Bembidion sp. & Bembidion & 11.86 & 30.60 & 15.00 & 54.40 & 0,21 \\
\hline Carabidae sp. & Carabidae & 18.01 & 31.40 & 34.20 & 34.40 & 0,05 \\
\hline Chondrula tridens & Ch_tridens & 14.48 & 18.60 & 36.50 & 44.90 & 0,04 \\
\hline Geophilus proximus & G_proximus & 12.92 & 7.70 & 14.10 & 78.20 & 0,05 \\
\hline Lepidoptera sp. & Lepidoptera & 12.61 & 11.70 & 24.60 & 63.70 & 0,38 \\
\hline Limax sp. & Limax & 8.49 & 45.50 & 24.30 & 30.30 & 0,26 \\
\hline Lumbricus rubellus & L_rubellus & 11.60 & 4.70 & 8.50 & 86.80 & 0,23 \\
\hline Megaphyllum rossicum & M_rossicum & 9.66 & 42.00 & 21.40 & 36.70 & 0,16 \\
\hline Melolontha melolontha & M_melolontha & 9.69 & 10.80 & 13.70 & 75.50 & 0,58 \\
\hline Octolasion lacteum & O_lacteum & 9.77 & 42.40 & 22.90 & 34.80 & 0,05 \\
\hline Schizothuranius dmitriewi & Sch_dmitriewi & 12.93 & 17.90 & 41.20 & 40.80 & 0,32 \\
\hline Trachelipus rathkii & T_rathkii & 12.94 & 30.60 & 31.00 & 38.40 & 0,05 \\
\hline Zonitoides nitidus & Z_nitidus & 14.02 & 21.50 & 13.10 & 65.40 & 0,15 \\
\hline \multicolumn{2}{|l|}{ Total OMI I } & - & 2.88 & - & - & 0.01 \\
\hline
\end{tabular}

Note: OMI - outlying mean index; Tol - the tolerance index, Rtol - residual tolerance index; indices represent the corresponding percentage of the variability; p-level - Monte Carlo test p-level after 999 permutation.

Marginality, which was significantly different from the random alternatives, was typical for 7 species of the 16 which were subject to OMI-analysis (Table 3 ). Thus, for a large number of species the typical edaphic conditions of the studied polygon do not coincide with the centroid of their ecological niche. Marginality of the niches indicates the degree of difference of optimum conditions for the species from conditions typical within a given habitat. Tolerance of niche is the inverse of specialization: the more tolerance, the less specialization. Residual tolerance indicates the role of random neutral factors and measurement errors. Species such as Zonitoides nitidus, Megaphyllum rossicum, Octolasion lacteum are characterized by high marginality and specialization (low tolerance). Thus, the studied habitat for these species is very extreme, and within this they occupy a very limited number of microstations. Species such as Schizothuranius dmitriewi, Chondrula tridens and Trachelipus rathkii are tolerant to the conditions within the habitat. Residual tolerance is large enough for a number of species (for Lumbricus rubellus is $86.8 \%$, for Geophilus proximus is $78.2 \%$ ), which suggests a significant role in structuring communities of soil factors of a neutral nature.

Configuration of the ecological niches of mesopedobionts is shown in Figure 2. Analysis of the data shown in Figure 2 indicates that a key aspect of the structuring of the ecological niche of soil animals is mechanical impedance in all soil layers of soil temperature (axis 1). Also, an important role is played by the electric conductivity of soil and herbage height (axis 2). The resulting visualization of the ecological niches of soil animals indicates that almost all niches are squeezed into the zone of lower soil mechanical impedance 
at all depths. This indicates a significant environmental impact of soil mechanical impedance on mesopedobionts.

RLQ analysis results are shown in Table 2 and Figure 3. It was found that $91.1 \%$ of the total variation (total inertia) describe the first two RLQ axes $(81.5 \%$ and $9.6 \%$ respectively). Randtest procedure confirmed the importance of RLQanalysis of the results on the district level 0.002. RLQ axes are integral estimates of the relationship between environmen- tal factors (in our case these are edaphic characteristics, litter depth and height of the grass), the structure of the community and its ecomorphic organization. In one metric space we are able to display the community structure (location of the mesopedobiont species), sampling point (spatial component considering the fact that the coordinates of sampling points were recorded), the weight factors of the environment and animal weight ,ecomorphic soil characteristics (Fig. 3).
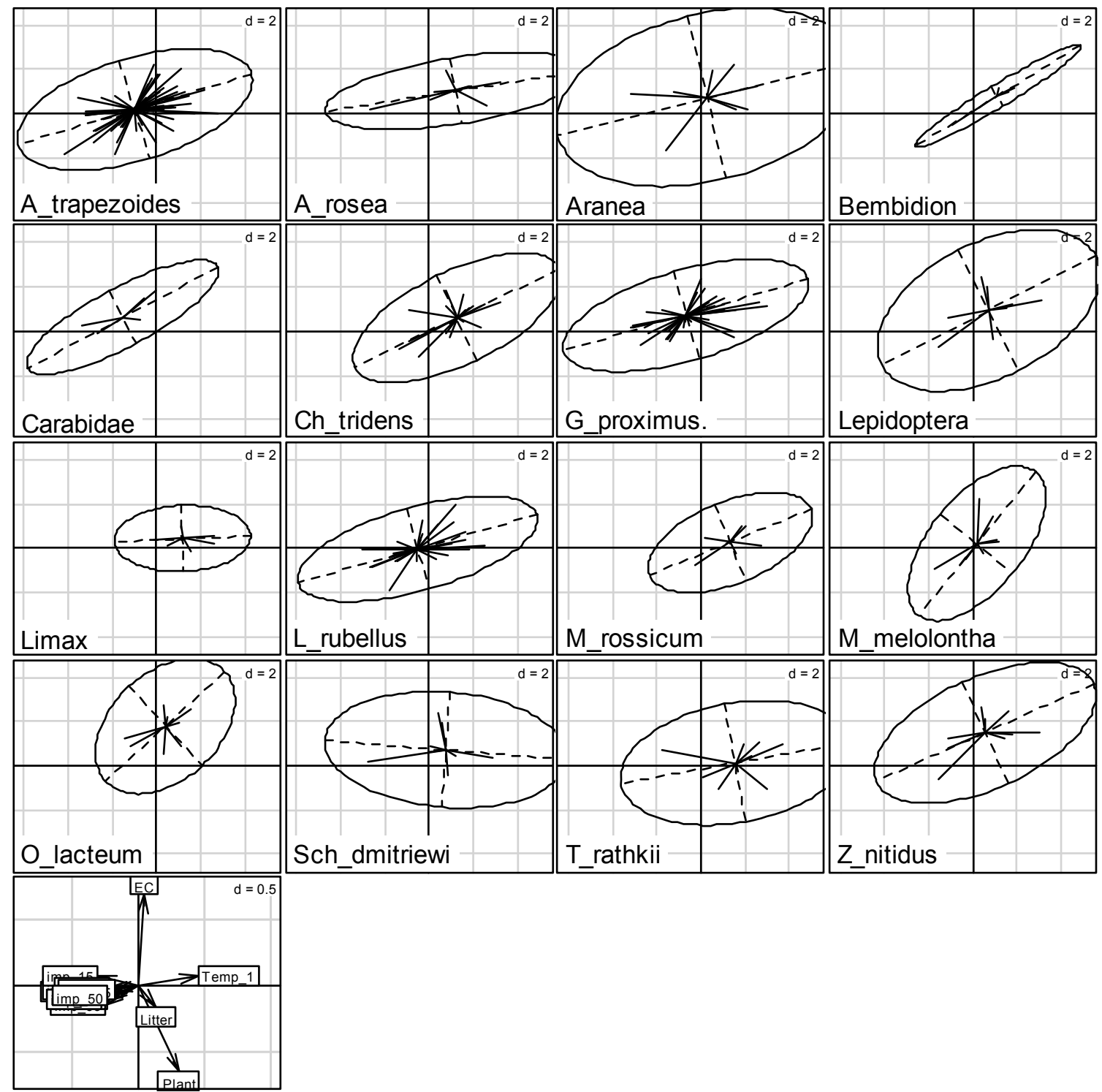

Fig. 2. Ecological niches of mesopedobionts:

coordinate axes are axes 1 and 2 obtained after OMI-analysis; origin - zero marginality; the ellipse represents the inertia of the ecological niche; rays associate centroid of the ecological niche with the meeting sites in the space of community marginality; in the lower right corner are normalized weights of environmental variables; abbreviation of the name of species - see Table 3

RLQ axes 1 and 2 have been found to be determined by the variability of the soil mechanical impedance. A feature of the axis 1 is the synchronous nature of the impact, starting at a depth of $10-15 \mathrm{~cm}$. For axis 2 is characterized by the growth of the impact with the depth and the maximum level of determination of soil mechanical impedance from a depth of 25-30 cm. An important marker of axis 1 is the temperature of the soil, and axis 2 is the height of grass.

RLQ-analysis allows us to classify the animals by the nature of their ecological structure and due to environmental factors. Cluster analysis allowed us to identify four complex- es of species which form functional groups A, B, C and D (Fig. 4). The location of these functional groups in the space of RLQ-axes is shown in Figure 5. All functional groups are located mainly in the field of positive values of the axis 1 , which corresponds to areas with lower soil mechanical impedance.

Centroids of functional groups A and B are the closest to the origin, which indicates that the representatives of these groups occupy the most common sites for the polygon. The functional group $\mathrm{A}$ is represented by the endogeic earthworms, which due to its capacity for active burrowing is 
less sensitive than other groups to the limiting effect of the soil mechanical impedance. The ecological characteristics of this group are that it belongs to the endogeic mesophyllous, mesotrophocoenomorph, phoromorph B4 categories.

The most extreme position along the RLQ 1 axis is occupied by representatives of functional group $\mathrm{D}$, which consists of epigeic molluscs. Probably among of the complex factors that characterize RLQ 1 axis litter depth is the most important for positioning of the group D. The ecological markers of the positive value of axis 1 are the diverse collection of environmental characteristics of soil animals, some of which are an opposite in nature. For example, it is a combination of the ecologically opposite ultrahygrophyllous and xerophyllous or combination of the silvants and stepants. Obviously, this fact suggests that hygromorphs and coenomorphs are not important aspects in the creation of the structural units of the animal community, shown in the axis 1 . The variability of axis 1 is important for topomorphs (close connection with the litter layer) and trophomorphs (high proportion of herbivores).

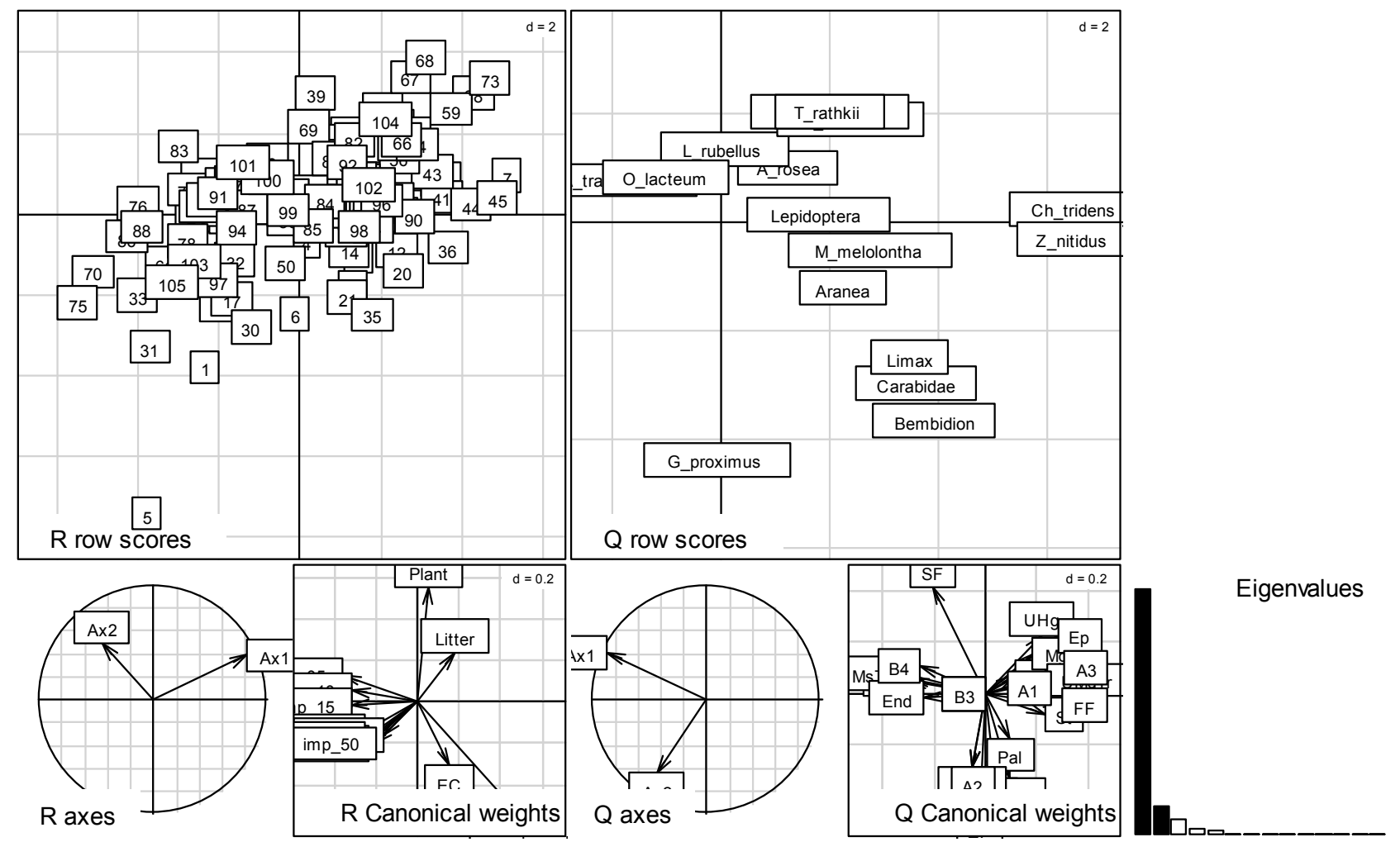

Fig. 3. The results of RLQ analysis: the axis of abscissa is RLQ-1 axis, the axis of ordinate is RLQ-2 axis, A are the weights of the sampling points (R-matrix) in the space constructed from RLQ-axes; B are the weights of the species in the space constructed from RLQ-axes (Q-matrix); C is the correlation principal component 1 and 2, based on factor analysis of environment variables with RLQ-axes; D is the correlation of environment variables with RLQ-axes; $\mathrm{E}$ is the correlation of the principal components 1 and 2 obtained by factor analysis of the ecomorphs with RLQ-axes; F is the correlation of the ecomorphs with RLQ-axes; G is a histogram of the eigenvalues

The ecological specificity of the functional groups B and $\mathrm{C}$ is determined by their opposite positions along the axis 2 . The group B is characterized by the predominance of saprophages, and the group $\mathrm{C}$ is characterized by the predominance of zoophages. The functional group B has been found to respond positively to the height of the grass and depth of the litter, but negatively to the soil mechanical impedance. The soil mechanical impedance can be seen not only as a factor that restricts the movement of animals in the soil, but also as an indicator of the ability to move and burrow in the soil system, if already set up. In this context, it can be considered that there is a positive relationship between the soil mechanical impedance and the functional group $\mathrm{C}$.

Spatial distribution of the RLQ-axis values is shown in Figure 6. The variation RLQ-1 axis linear trend describes only $7.7 \%$ of the variance, while in the regression model, which acts as a predictor of geographical coordinates, is va- lid only the y-axis. Linear trend RLQ-axis 2 describes $10.3 \%$ of the variance. Thus, for both axes linear trend is not a key feature of the spatial organization of the community of soil macrofauna.

The figures which reflect the spatial variability of the RLQ axis 1 and axis 2 show typical areas with high and low values of the axes which have an irregular oval (amoeboid) form. Analysis of the data presented earlier indicates that spatial patterns induced by factors connected with RLQ axis 1 are most closely associated with the heterogeneity of soil conditions within the polygon, as a marker of that axis is the soil mechanical impedance throughout the soil profile, within which the measurements were taken. Probably related to this is the great contrast and tortuous nature of the structural boundaries corresponding to spots of spatial pattern. RLQ axis 2 is also marked by soil mechanical impedance, but another important marker is the height of the grass. It can be 
assumed that in the case of RLQ axis 2, the soil mechanical impedance is no longer a cause of variability of environmental conditions but this soil property may be considered as a consequence of the spatial organization of plant cover. It is known that vegetation is a significant modulator of many soil properties and soil mechanical impedance (Medvedev, 2008). Thus, we can conclude that the RLQ-1 axis, showing the relationship of soil conditions and environmental properties with the animal community, is caused by pedogenic factors. In turn, RLQ2 axis reflects the convening role of phytogenic factors, the effects of which on soil mesopedobionts are also refracted through the transformation of soil conditions.

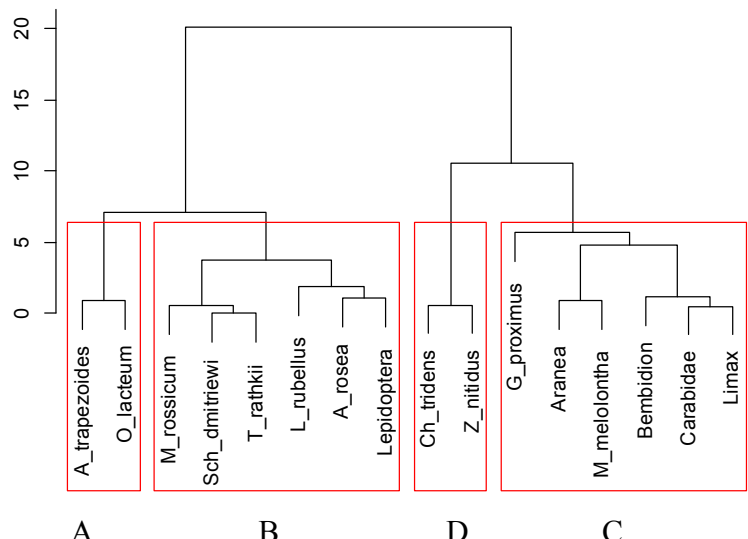

Fig. 4. Cluster analysis of the mesopedobiont community structure

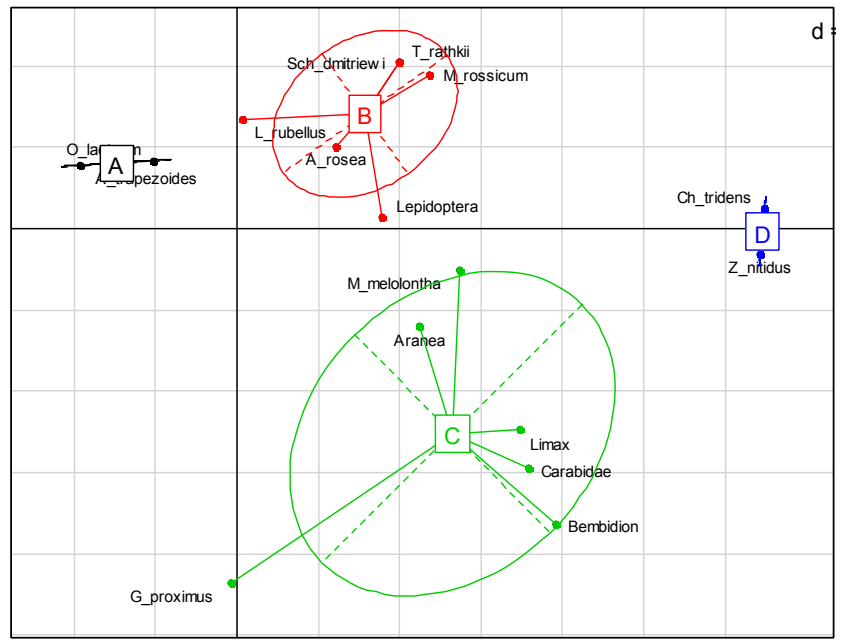

Fig. 5. An arrangement of functional groups in the RLQ-axes space
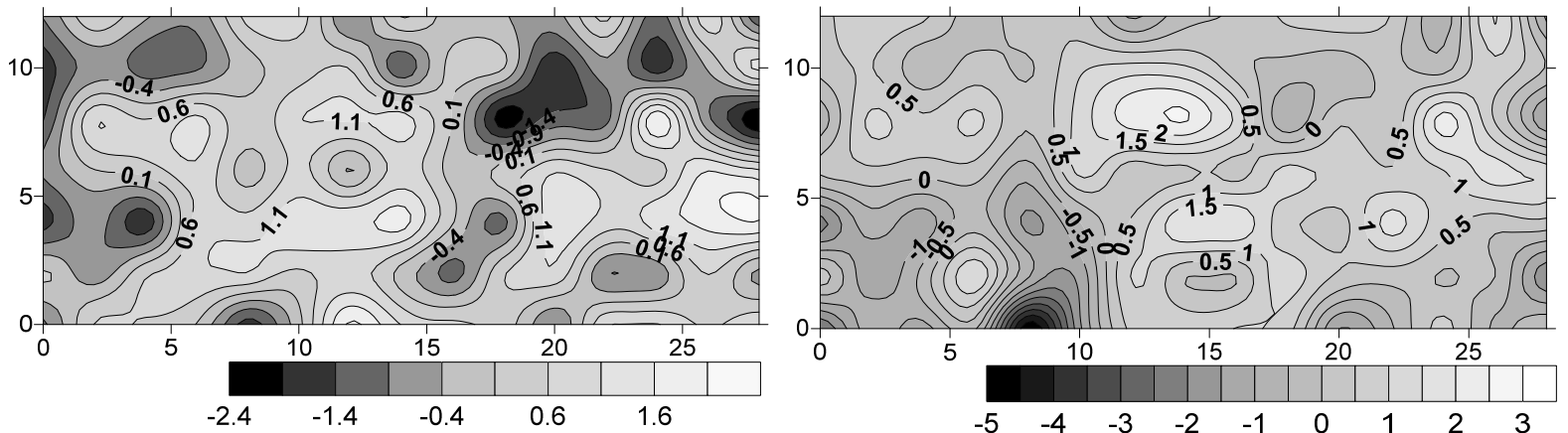

Fig. 6. Spatial variability of RLQ-axes

\section{Discussion}

It is possible to apply morphological or physiological characteristics of animals in order to assess the degree of species differences applicable to homogeneous taxonomic or ecological groups with comparable characteristics, which can also be interpreted ecologically. Soil macrofauna presents a high degree of the taxonomic and ecological diversity of forms, which are difficult to compare on the basis of the morphological or physiological criteria. Ecological saturation of the characteristics in different groups will not be the same. The basis for comparison would be uneven. Therefore, to describe the ecological properties of mesopedobionts we use ecomorphic analysis of soil animals (Zhukov, 2009).

Pokarzhevskiy et al. (2007) consider community organization of the soil animals at the levels of investigated point, biogeocenosis, landscape and regional level. An ecomorph 
may be considered as an ecological group. In order to assess a species as belonging to a particular ecomorph, the distribution of the species in ecological space at the landscape level has to be studied. A different direction of ecomorph selection at the landscape level conventionally considered to be independent and forming the ecological matrix (in multidimensional space) is the multidimensional matrix, or tensor (Zhukov, 2010). At the level of the biogeocoenosis the degree of the different ecomorphs correlativity is likely to be higher, so the soil animals will form local, but functionally significant, groupings. The regular ecomorph ratio in these functional groups will be a reflection of their organizational structure and ecological diversity.

Our results indicate that the mechanical impedance of the soil is an important factor that structures the ecological niches of soil animals. It should be noted that variations in the soil mechanical impedance influence not only quantitative changes of the animal community of soil and vegetation (Zhukov and Zadorozhnaya, 2016), but also qualitative adjustments in the structure of the biotic communities. We received evidence that quantitative adjustments of the mesopedobiont community are accompanied by a transformation of the functional structure, which leads to the formation of spatially and functionally isolated groups of soil animals.

It is important to note the fact that the functional groups identified in ecological space by means of RLQ-analysis demonstrate regular patterns of spatial variability. Local functional groups are characterized by ecological characteristics, which may by presented in terms of ecomorphs. Functional group A can be described as a complex of endogeic mesophyllous, mesotrophoceonomorphs, phoromorphs of the type B4. This group is the least affected of all the established groups by high values of soil mechanical impedance due to the ability of its representatives to burrow actively. The representatives of the functional group D are characterized by opposite functional properties. Functional group D is presented by epigeic and phytophagous forms, which determines the sensitivity of this functional group to the litter depth. The functional groups $\mathrm{B}$ and $\mathrm{C}$ may be differentiated on the basis of trophic specialization. Functional group B is characterized by the predominance of saprophages. Functional group $\mathrm{C}$ is characterized by the predominance of zoophages. Functional group B tends to inhabit microstations with greater litter depth and lower soil mechanical impedance value. Functional group $\mathrm{C}$ tends inhabit to microstations with greater soil mechanical impedance value, which may be due to the greater safety of the soil system moves in such conditions.

\section{Conclusions}

The community of the urbotechnozem mesopedobionts was represented by 28 species with density of $70.1 \pm$ $15.7 \mathrm{ind} . / \mathrm{m}^{2}$. The dominant group of soil animals was earthworms, which were represented by 4 species. In the structure of the community earthworms made up $61.6 \%$ of the total population. Coenomorphic features of the animal community within the studied polygon can be characterized as a meadow type with the steppe and forest elements. The community was dominated by mesophyllous, mesotrophocoenomorph, endogeic, saprophages, and also animals which actively burrow by changing body shape.

The community of urbotechnozem mesopedobionts was structured within the polygon in spatial and ecological aspects. The main animal community structuring factor was the mechanical impedance of the soil. Quantitative changes in community abundance as a reaction to variation of mechanical impedance of the soil in horizon and vertical directions was accompanied by transformation in the functional structure of the community. This transformation may be detected in terms of ecomorphs. Spatial variation of the community's functional structure generates regular spatial patterns.

\section{References}

Andrisevich, K.V., Zhukov, A.V., Kunah, O.N., 2014. Ecomorphic organisation of the mesopedobionts community as the basis of the anthropogenic soils zoological diagnostic. The Journal of V.N. Karazin Kharkiv National University 22, 89-97.

Angermeier, P.L., 1998. Local vs regional influences on local diversity in stream fish community of Virginia. Ecology 79, 911-927.

Austen, D.J., Bayley, P.B., Menzel, B.W., 1994. Importance of the guild concept to fisheries research and management. Fisheries 19, 12-20.

Baljuk, J.A., Kunah, O.N., Zhukov, A.V., Zadorozhnaja, G.A., Ganzha, D.S., 2014. Sampling adaptive strategy and spatial organisation estimation of soil animal communities at various hierarchical levels of urbanised territories. Biol. Bull. 4(3), 8-33.

Belgard, A.L., 1950. Forest vegetation of South-Eeast part of the USSR. Kiev University Press, Kiev (in Russian).

Bernhardt-Romermann, M., Romermann, C., Nuske, R., Parth, A., Klotz, S., Schmidt, W., Stadler, J., 2008. On the identification of the most suitable traits for plant functional trait analyses. Oikos 117, 1533-1541.

Brind'amour, A., Boisclair, D., Legendre, P., Borcard, D., 2005. Multiscale spatial distribution of a littoral fish community in relation to environmental variables. Limnol. Oceanogr. 50(2), 465-479.

Brind'Amour, A., Boisclair, D., Dray, S., Legendre, P., 2011. Relationships between species feeding traits and environmental conditions in fish communities: A three-matrix. Ecol. Appl. 21(2), 363-377.

Brygadyrenko, V.V., 2015. Community structure of litter invertebrates of forest belt ecosystems in the Ukrainian steppe zone. Int. J. Environ. Res. 9(4), 1183-1192.

Brygadyrenko, V.V., Komarov, O.S., 2008. Trofichna struktura pidstylkovoji mezofauny: Rozpodil biomasy za trofichnymy rivniamy [Trophic structure of litter mesofauna: Biomass differentiation between trophic levels]. Vìsn. Dnìpropetr. Unìv. Ser. Bìol. Ekol. 16(2), 12-23 (in Ukrainian).

Calinski, T., Harabasz, J., 1974. A dendrite method for cluster analysis. Commun. Stat. 3, 1-27.

Demidov, A.A., Kobets, A.S., Gritsan, Y.I., Zhukov, A.V., 2013. Spatial agricultural ecology and soil recultivation. A.L. Svidler Press, Dnepropetrovsk.

Doledec, S., Chessel, D., Ter Braak, C.J.F., Champely, S., 1996 Matching species traits to environmental variables: A new three-table ordination method. Environ. Ecol. Stat. 3, 143-166.

Dray, S., Pettorelli, N., Chessel, D., 2002. Matching data sets from two different spatial samples. J. Veg. Sci. 13, 867-874.

Faly, L.I., Brygadyrenko, V.V., 2014. Patterns in the horizontal structure of litter invertebrate communities in windbreak plantations in the steppe zone of the Ukraine. J. Plant Prot. Res. 54(4), 414-420. 
Gilarov, M.S., 1965. Zoological methods of the soils diagnostic. Nauka, Moscow (in Russian).

Kabar, A.N., 2003. Biological and ecological features of soil cover in Botanical garden of Dnepropetrovsk State University (formation, development, sustainable use). Dnepropetrovsk (in Russian).

Karpachevsky, L.O., 2005. Ecological soil science. Geos, Moscow.

Kunah, O.N., Zhukov, O.V., Balik, Y.A., 2013. Ecomorphic and spatial organization of mesopedobions of the forest park planting within Dnipropetrovsk. Problems of the Ecology and Nature Protection of the Technogenic Region 13, 106121 (in Russian).

Kunah, O.N., Zhukov, A.V., Balyuk, Y.A., 2013. Prostranstvennaya organizatsiya soobschestva mezopedobiontov urbotehnozema [The spatial organization of the urbotechnozem mesopedobionts]. Gruntoznavstvo 14(3), 76-97 (in Russian).

Kunah, O.N., Zhukov, A.V., Balyuk, Y.A., 2013. Prostranstvennoe varirovanie ekomorficheskoy strukturyi pochvennoy mezofaunyi urbazema [The spatial variation of soil mesofauna ecomorphic structure in urbazem]. Scientific Notes of Taurida National V.I. Vernadsky University. Series Biology and Chemistry 65, 107-126 (in Russian).

McGill, B.J., Enquist, B.J., Weiher, E., Westoby, M., 2006. Rebuilding community ecology from functional traits. Trends Ecol. Evol. 21(4), 178-184.

Medvedev, V.V., 2009. Tverdost pochvyi [Soil penetration resistance]. Gorodskaya Tipografiya, Kharkov (in Russian).

Minden, V., Andratschke, S., Spalke, J., Timmermann, H., Kleyer, M., 2012. Plant-trait environment relationships in salt marshes: Deviations from predictions by ecological concepts. Perspectives in Plant Ecology, Evolution and Systematics $14,183-192$.

Mirzak, O.V., 2001. Experience of the investigation of the great industrials centers of the steppe zone of the Ukraine (city Dnipropetrovsk as example). Gruntosnavstvo 1, 87-92 (in Russian).

Mouillot, D., Spatharis, S., Reizopoulou, S., Laugier, T., Sabetta, L., Basset, A., Do Chi, T., 2006. Alternatives to taxonomicbased approaches to assess changes in transitional water. Aquat. Conserv. Mar. Freshw. Ecosys. 16, 469-482.

Olden, J.D., Jackson, D.A., 2002. A comparison of statistical approaches for modelling fish species distributions. Freshwater Biol. 47, 1976-1995.

Pakhomov, A.E., Kunakh, O.M., Zhukov, A.V., Baliuk, Y.A., 2013. Spatial organisation of an ecological niche of the urbozem mesofauna. Vìsn. Dnìpropetr. Unìv. Ser. Bìol. Ekol. 21(1), 51-57 (in Russian).

Pokarzhevskiy, A.D., Gongalskiy, K.B., Zaycev, A.S., Savin, F.A., 2007. Spatial ecology of soil animals. KMK Scientific Press, Moscow (in Russian).

Santoul, F., Cayrou, J., Mastrorillo, S., Cereghino, R., 2005. Spatial patterns of the biological traits of freshwater fish communities in south-west France. J. Fish Biol. 66, 301-314.

Scoggins, H.L., van Iersel, M.W., 2006. In situ probes for measurement of EC of soilless substrates: Effects of temperature and substrate moisture content. HortScience 41, 210-214.

Shemavnev, V.I., Gordienko, N.A., Dirda, V.I., Zabaluev, V.A., 2005. The stable development of the complicated ecotechnosystems. Novaya Ideologia, Moscow, Dnipropetrovsk.
Smagin, A.V., Azovtseva, N.A., Smagina, M.V., Stepanov, A.L., Miagkova, A.D., Kurbatova, A.S., 2006. Some criteria and estimation methods of soil ecological conditions regards to greenery of urban areas. Soil Sciences 5, 603-615 (in Russian).

Tarasov, V.V., 2005. Flora Dnipropetrovs'koyi i Zaporiz'koyi oblastey [Dnipropetrovsk an Zaporozhie regions flora]. Dnipropetrovsk University Press, Dnipropetrovsk (in Ukranian).

Tarasov, V.V., 2012. Flora Dnipropetrovs'koyi i Zaporiz'koyi oblastey [Dnipropetrovsk an Zaporozhie regions flora]. Second ed. Lira, Dnipropetrovsk (in Ukranian).

Thuiller, W., Lavorel, S., Midgley, G., Lavergne, S., Rebelo, T., 2004. Relating plant traits and species distributions along bioclimatic gradients for Leucadendron taxa. Ecology 85, 1688-1699.

Tonn, W.M., Magnuson, J.J., Rask, M., Toivonen, J., 1990. Intercontinental comparison of small-lake fish assemblages: The balance between local and regional processes. Am. Nat. 136, 345-375.

Zadorozhna, G.O., Kunah, O.N., Zhukov, O.V., 2012. The spatial organization of soddy-lithogenic soils on the redbrown clays. Problems of the Ecology and Nature Protection of the Technogenic Region 12, 226-237.

Zhukov, A.V., Zadorozhnaya, G.O., 2013. Spatial variability of pedozems mechanical impedance. Biol. Bull. 1(7), 34-49.

Zhukov, A.V., 2006. Hygromorphes of the soil animals and their purpose for hygrtopes assessment. Problems of the Ecology and Nature Conservation of the Technogenic Region 6, 113-130.

Zhukov, A.V., 2007. Soil animal trophocoenomorphes and their diagnostic importance for gygrotops indicating. Visnyk of Donetsk University. Natural Science 277-291 (in Russian).

Zhukov, A.V., 2010. Belgard - Akimov's ecomorphes and ecological matrix. Ecology and Noospherology 21, 109-111.

Zhukov, A.V., Kunah, O.N., Konovalova, T.M., 2013. Spatial distribution of mole rat (Spalax microphthalmus) mounds and soil penetration resistance. Povolzhskiy Journal of Ecology $1,3-15$.

Zhukov, A.V., Kunah, O.N., Prokopenko, E.V., Konovalova, T.M., 2011. The pedoturbation activity of the mole rats (Spalax microphthalmus) as a factor of the spatial organization of the spider (Aranei). News of Dnipropetrovsk State Agrarian and Economic University 6, 28-35.

Zhukov, A., Zadorozhnaya, G. 2016. Spatial heterogeneity of mechanical impedance of a typical chernozem: The ecological approach. Ekológia (Bratislava), 263-278.

Zhukov, O.V., 2006. The ecomorphic analysis of the soil animals consortia. Svidler Press, Dnipropetrovsk.

Zhukov, O.V., Kunah, O.M., Baluk, Y.O., 2014. Spatial variation of the ecomorphic structure of the soil mesofauna of the forest park planting (park within Dnipropetrovsk as example). Bulletin of L'viv University. Biological Issue 65, 224-237.

Zobel, M., 1997. The relative role of species pools in determining plant species richness: Alternative esplanation of species coexistence? Trends Ecol. Evol. 12, 266-269.

Надійшла до редколегї 11.09.2016 